\title{
Acanthophyllia deshayesiana (Michelin, 1850) Coral Species Is Not Synonym With Cynarina lacrymalis (Milne Edwards \& Haime, 1848)
}

\author{
Robba Fahrisy Darus ${ }^{1 *}$, Neviaty P Zamani², Suharsono³ ${ }^{3}$ and Dedy Duryadi Solihin ${ }^{4}$ \\ 1,2Department of Marine Science, Bogor Agricultural University, Indonesia \\ Jl. Rasamala, Bogor, West Java, Indonesia 16680 \\ ${ }^{3}$ Research Center for Oceanography, Indonesian Institute of Sciences \\ Jl. Pasir Putih I, Ancol Timur Jakarta Utara, Indonesia 11048 \\ 4 Departement of Biology, Faculty of Mathematics and Natural Science, Bogor Agricultural University \\ Jl. Meranti, Kampus IPB Darmaga, Bogor, Indonesia 16680 \\ e-mail: robba_madura@yahoo.co.id
}

\begin{abstract}
Acanthophyllia deshayesiana has a different habitat with Cynarina lacrymalis in the nature, but they have same character on living forms, diameter, and height of corallite. Both of these species are considered synonym, thus it needs verification study to describe whether it is synonym species or not based on morphological data. Eleven descriptive characters and seven morphometric characters were used to verify the synonym species of these coral. Descriptive data were performed by scoring method, while morphometric data were obtained from morphometric. Morphometric data were analyzed by Correspondence Analysis of Principal Coordinates (CAP) and Agglomerative Hierarchical Cluster (AHC), while descriptive data were analyzed by UPGMA (Unweight Pair Group Method with Arithmetic Mean). The result showed that both of these coral can not differentiate based on morphometric measurement. It can differentiate significantly based on descriptive characters, so both of these coral are not synonym.
\end{abstract}

Keywords: synonym, morphometric, descriptive, Cynarina lacrymalis, Acanthophyllia deshayesiana

\section{Introduction}

Generally, morphological pattern of organisms were influenced by genetic factors which are inherited from the parent. Heritable genetic information does not always provide significant influences, because there is environmental component that can influence the morphological pattern. The environmental response of each organism is different and can cause genetic mutations or slow growth. Organism will adapt to respond environmental changes.

One of organisms that have more responses to environmental changes is coral. High response of coral to environmental changes (Wolstenholme et al., 2003; Marti-Puig et al., 2014) have an impact on morphological pattern of the coral diversity, so it classified in a high plasticity organisms (Stefani et al., 2008; Huang et al., 2009; Schmidt-Roach et al., 2012). The diversity of coral morphology gives a trouble to identify live coral and classification system in the coral taxonomy.

Classification and systematic of coral was done using traditional classification that is morphology of the skeleton (Wolstenholme et al., 2003; Schmidt-Roach et al., 2012; Arrigoni et al., 2014b) and purposed to know their relationship and evolution (Stobart, 2000; Flot et al., 2008; Casebolt, 2011). However, the observation and measurement of coral using skeleton showed intra species variation and a high plasticity (Stefani et al., 2008). Therefore, there were many studies on the coral systematics by combining the morphological and molecular approach.

Morphological diversity causes difficulties on coral dead to be classified into one group and given the same name (Flot et al., 2008; Schmidt-Roach et al., 2012). For example coral Cynarina lacrymalis were usually considered as a synonym of Acanthophyllia deshayesiana. It was described by Best and Hoeksema (1987) in which had a same variation with $C$. lacrymalis. The similarities were solitary life, had a diameter of corallite $10 \mathrm{~cm}$, calice relief $8 \mathrm{~cm}$, tooth high in primary septal is $15 \mathrm{~mm}$, epitheca well developed, and the corallum was strongly dentated. The holotype of $C$. lacrymalis is in MNHN (Muse 'um National d'Histoire Naturelle, Paris, France) with Philliphines as local type of it. 
The synonym problem of species would impact on the trade regulation of ornamental coral and lead to legality. This study aimed to verify suspected synonym of two species, i.e. ( $A$. deshayesiana and $C$. lacrymalis) based on morphological characters. Morphological characters used two characters in this study, consist of descriptive and morphometric characters. Those characters were assumed to be able differ and could be character identifier in the cladogram.

\section{Materials and Methods}

Seven corals of $C$. lacrymalis taken from Kalimantan and eight corals of $A$. deshayesiana taken from Makassar were used this study from Family Mussidae (Figure 1). Coral specimens were bleached in sodium hyplocorite, rinsed with freshwater, and air-dried for morphological analysis. Morphological analysis were consist of morphometric and descriptive characters (Oppen et al., 2000; Wolstenholme et al., 2003; Stefani et al., 2008; Filatov et al., 2013; Kitano et al., 2014). Coral specimens were selected by the same size (the colony diameter range $4-8 \mathrm{~cm}$ ).

Observations of descriptive characters were done by taking a picture using Canon powershoot D30. Morphometric characters used a caliper (accuracy $0.01 \mathrm{~mm}$ ) as the reference length (Stefani et al., 2008). Morphometric characters involved 7 characters (Figure 2 and Table 1) (Budd and Stolarski, 2009; Casebolt, 2011; Arrigoni et al., 2012; Benzoni et al., 2012; Budd et al., 2012; Arrigoni et al., 2014a; 2014b).

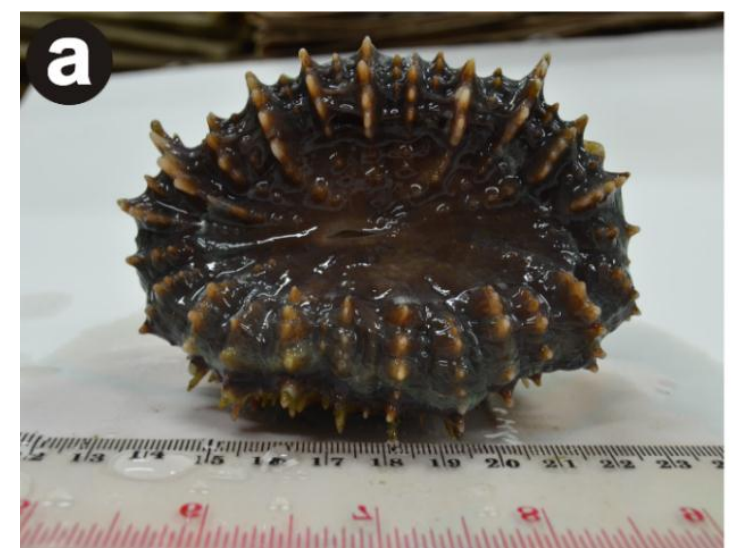

(a)

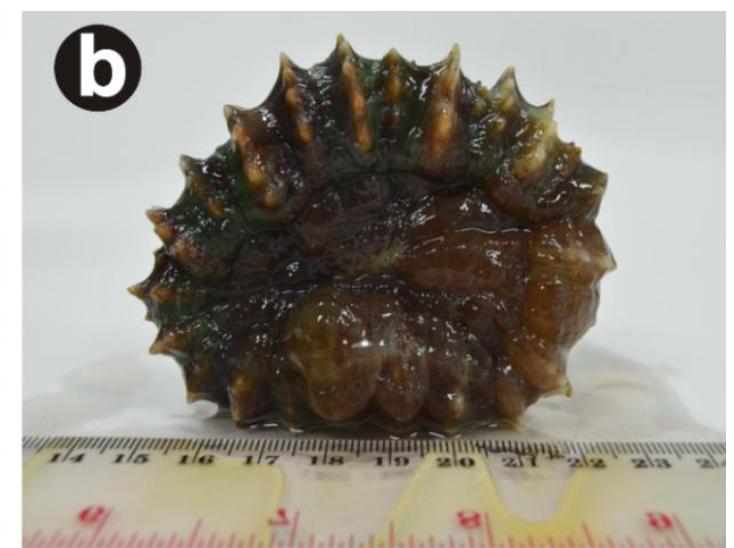

(b)

Figure 1. The living conditions of corals: (a) Acantophyllia deshayesiana; (b) Cynarina lacrymalis
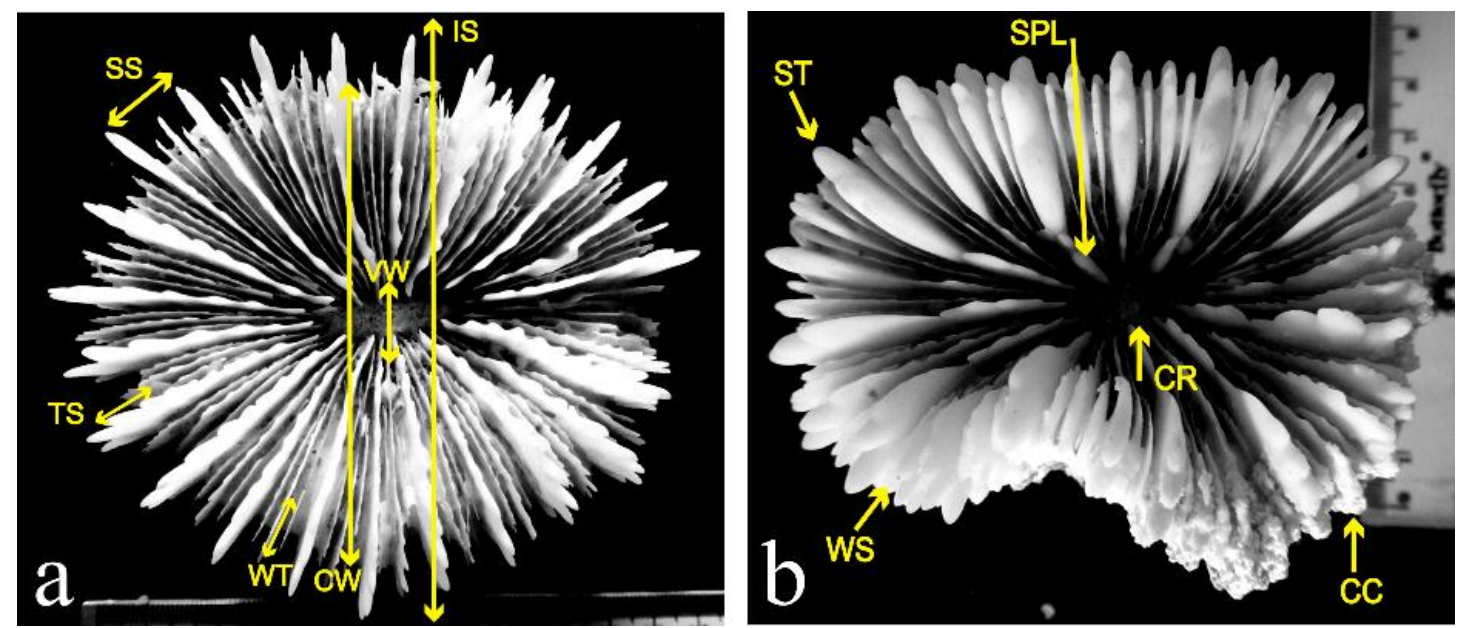

Figure 2. Corallite features were analyzed in morphological studies on C. lacrymalis \& A. deshayesiana: a) morphometric characters; $\&$ b) descriptive characters. SS $=$ Septa Spacing, TS $=$ Tooth Spacing, IS = Individual Size, $\mathrm{VW}=$ Valley Width, $\mathrm{CW}=$ Calice Width, $\mathrm{WT}=$ Wall Thickness, $\mathrm{ST}=$ Septal Teeth, $\mathrm{WS}=$ Wall Structure, $\mathrm{SPL}=$ Septal or Paliform Lobes, $\mathrm{CR}=$ Calice Relief, and CC $=$ Continuity of Costae. 
Table 1. Morphometric characters which were used to measure corallite features

\begin{tabular}{cll}
\hline No. & \multicolumn{1}{c}{ Character } & \multicolumn{1}{c}{ Description } \\
\hline 1 & Calice Width (CW) & Diameter of calice in corallite \\
2 & Valley Width (VW) & Diameter of valley in corallite \\
3 & Calice Relief (CR) & Corallite depth from valley \\
4 & Tooth Height (first order septum) (TH) & Average of tooth height in first septa \\
5 & tooth Spacing (first order septum) (TS) & Average of tooth spacing from one another tooth septa \\
6 & Overall Wall Thickness (WT) & Wall thickness from corallite \\
7 & Individual Size (IS) & Diameter of individual coral \\
\hline
\end{tabular}

Table 2. Descriptive characters used to describe corallite

\begin{tabular}{|c|c|c|c|}
\hline No & Character & State & Code \\
\hline \multirow[t]{7}{*}{1} & Corallite Shape (CS) & plocoid & 0 \\
\hline & & subplocoid & 1 \\
\hline & & cerioid & 2 \\
\hline & & meandroid & 3 \\
\hline & & flabelloid & 4 \\
\hline & & phaceloid & 5 \\
\hline & & solitary & 6 \\
\hline \multirow[t]{3}{*}{2} & Septal Teeth (ST) & minute & 0 \\
\hline & & acute or small & 1 \\
\hline & & large & 2 \\
\hline \multirow[t]{3}{*}{3} & Budding Type (BT) & intramural & 0 \\
\hline & & extramural & 1 \\
\hline & & none & 2 \\
\hline \multirow[t]{2}{*}{4} & Continuity of Costae (CC) & continous & 0 \\
\hline & & dis-continous & 1 \\
\hline \multirow[t]{4}{*}{5} & Septal and Paliform Lobes (SPL) & pali & 0 \\
\hline & & sometimes paliform & 1 \\
\hline & & sometimes septal & 2 \\
\hline & & none & 3 \\
\hline \multirow[t]{5}{*}{6} & Columella Structure (CLS) & trabecular \& continous & 0 \\
\hline & & trabecular \& discontinous & 1 \\
\hline & & styliform & 2 \\
\hline & & lamellar & 3 \\
\hline & & absent & 4 \\
\hline \multirow[t]{5}{*}{7} & Wall Structure (WS) & parathecal & 0 \\
\hline & & septothecal & 1 \\
\hline & & septothecal or/and parathecal & 2 \\
\hline & & synapticulothecal & 3 \\
\hline & & none & 4 \\
\hline \multirow[t]{2}{*}{8} & Costae Pattern (CP) & equal & 0 \\
\hline & & unequal & 1 \\
\hline \multirow[t]{3}{*}{9} & Costae Dentation (CD) & fine & 0 \\
\hline & & short & 1 \\
\hline & & exsert & 2 \\
\hline \multirow[t]{2}{*}{10} & Costae Alignment (CA) & absent & 0 \\
\hline & & present & 1 \\
\hline \multirow[t]{3}{*}{11} & Coenosteum (CO) & absent & 0 \\
\hline & & smooth & 1 \\
\hline & & blistered & 2 \\
\hline
\end{tabular}


Descriptive characters involved 11 characters (Figure 2 and Table 2) (Budd and Stolarski, 2009; Casebolt, 2011; Arrigoni et al., 2012; Benzoni et al., 2012; Budd et al., 2012; Arrigoni et al., 2014a; 2014b).

Morphometric data were analyzed by Correspondence Analysis of Principal Coordinates (CAP), and hierarchical cluster by Agglomerative Hierarchical Clustering ( $\mathrm{AHC}$ ) to know the separation of species groups using XLSTAT 2015 (Wolstenholme et al., 2003; Stefani et al., 2008). Unweighted Pair Group Method with Arithmetic Mean (UPGMA) was used to analyze descriptive data using PAUP 4 (Swofford, 2002; Arrigoni et al., 2012; Benzoni et al., 2012; Arrigoni et al., 2014b) to reconstruct phylogeny tree based on descriptive characters.

\section{Results and Discussion}

\section{Morphometric characters}

Based on the symmetric plot graph of CAP and $\mathrm{AHC}$, there were five clades which interpret a relationship between morphometric characters with coral specimens, which was clade 1 (ACT3, ACT11, ACT7, ACT19, АCT21, АCT1, and ACT41), clade 2 (ACT10, CYN40, CYN39, and CYN48), clade 3 (ACT12, and CYN55), clade 4 (CYN45), and clade 5 (CYN59).
Clade 1 was grouped by Calice Width (CW), and Valley Width (VW) character. In addition, clade 1 was divided into small clades, namely the clade $1 \mathrm{a}$ (ACT11 and ACT1), and 1b (ACT21, ACT19, ACT7, ACT3, and CYN41). Clade $1 \mathrm{~b}$ was subdivided into 1b1 (ACT21 and ACT19), and 1b2 (CYN41, ACT3, and ACT7). Clade 1a was closer grouping based on VW, while clade $1 \mathrm{~b}$ was classified by CW (Figure 4). Calice and valley width always directly proportional to ratio was $1: 0,25 \%$, and the value for calice and valley width on C. lacrymalis was $>30 \mathrm{~mm}$ (Budd and Stolarski, 2009). Cynarina lacrymalis is a large coral polyps that have the largest calice and valley width in Famili Mussidae compared to Genus Favia which had ranges between $9-15 \mathrm{~mm}$ (Kongjandtre et al., 2012).

Clade 2 was grouped by Calice Relief (CR) (Figure 3). Calice relief of these five corals were more related and had relatively same value was $18,770 \mathrm{~mm}$ to $22,650 \mathrm{~mm}$. Calice relief on C. lacrymalis was classified to a very high category which was > $10 \mathrm{~mm}$ (Budd and Stolarski, 2009). Calice form is influenced by calice width, which the wider a calice, then the smaller its relief (Kongjandtre et al., 2012; Huang et al., 2014).

Clade 3 consisted of ACT12 and CYN55 which were grouped based on individual size (IS) (Figure 3). The CAP showed that position of ACT12 was a bit far from the group, however the $\mathrm{AHC}$ was in one group with an equal value of $99,77 \%$ (Figure 4 ).

Symmetric plot

(axes F1 and F2: $62.65 \%$ )

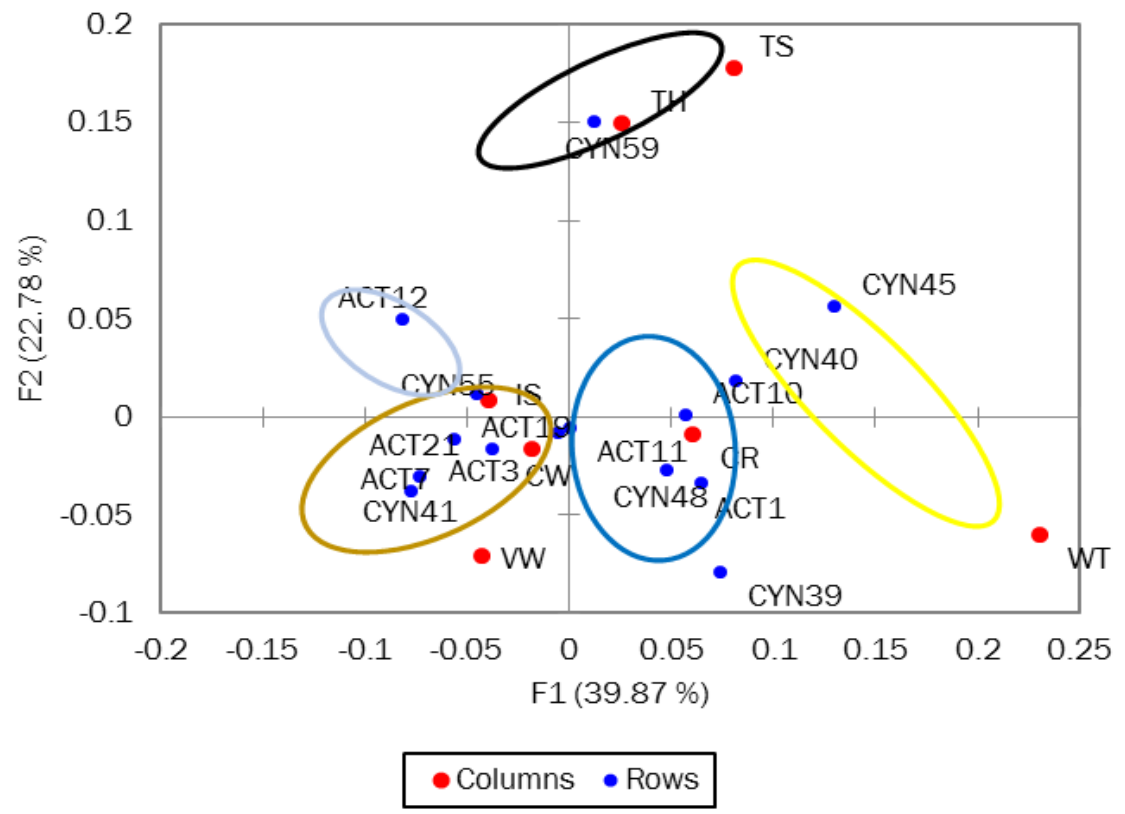

Figure 1. Grouping coral C. lacrymalis and A. deshayesiana based on morphometric characters using Correspondent Analysis of Principal Coordinates (CAP) 


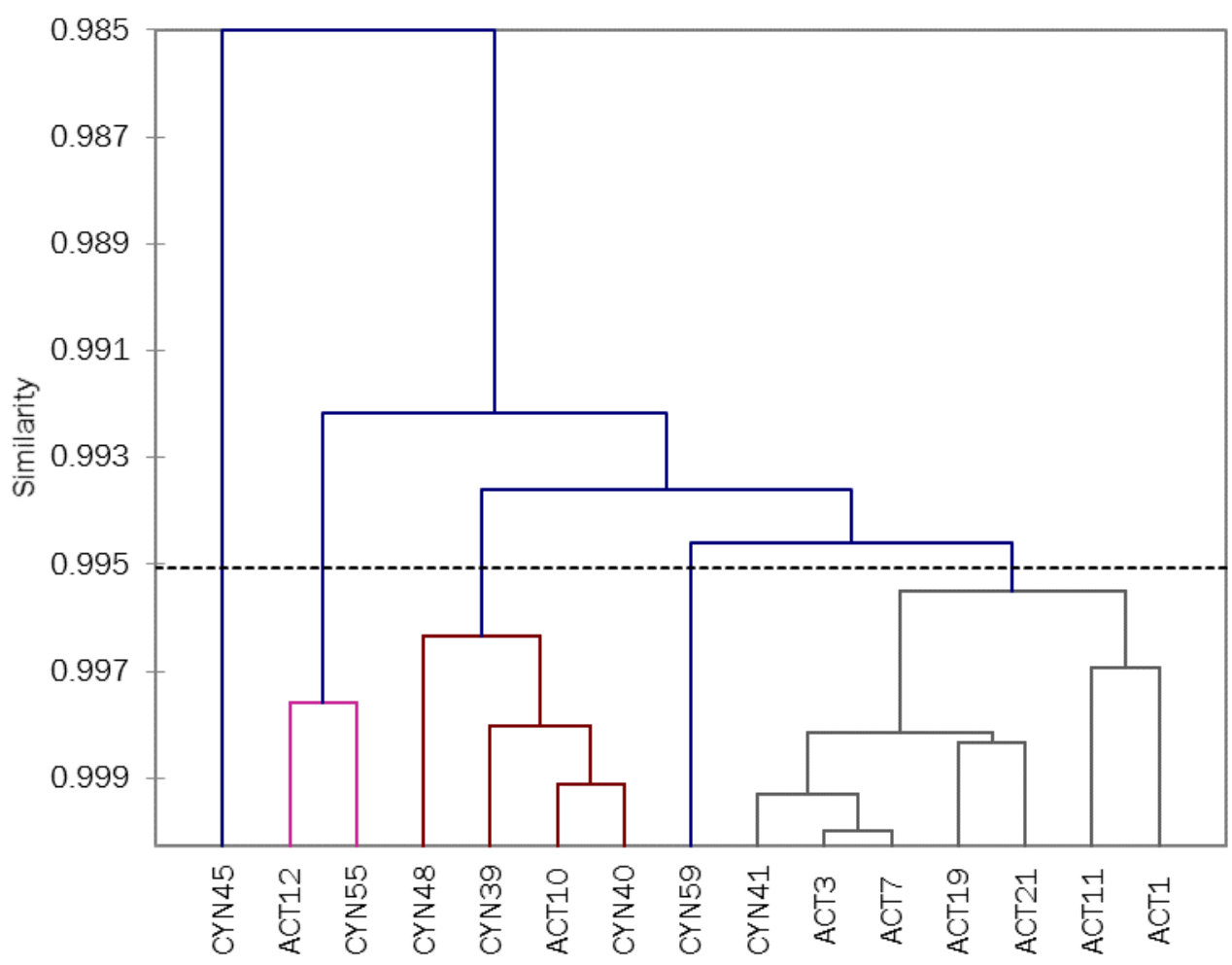

Figure 2. Dendogram of coral C. lacrymalis and A. deshayesiana based on morphometric characters using Agglomerative Hierarchical Clustering (AHC)

Individual size is directly proportional to the calice and valley width. In addition, individual size is strongly influenced by the age and growth of coral. The age and growth of coral that are more mature, it will have a wide valley and calice.

Clade 4 was CYN45 with a character grouping by wall thickness (WT). Wall thickness value of CYN45 was almost same with another specimen, however, the other morphometric characters did not influence the grouping of another specimen. Based on AHC result, CYN45 grouped itself because the value of the Calice Width (CW), Valley Width (VW), Tooth Height (TH), and Individual Size (IS) was very small, so that the level of similarity was low $(98,5 \%)$. These conditions were almost same with clade 5 consisted of CYN59 with a character grouping were Tooth Height (TH) and Tooth Spacing (TS) on the first order septa. CYN59 had the same TH and TS value reltively in the amount of 5,342 $\mathrm{mm}$ and 5,624 $\mathrm{mm}$. The TS value was measured at the highest tooth (first septa peak). The TS value of $A$. deshayesiana and $C$. lacrymalis had a range from $0,3 \mathrm{~mm}$ to 0,6 $\mathrm{mm}$ in the first septa (Figure 6). Both of these values had similar results obtained by Budd and Stolarski (2009) that value of distance between the teeth of C. lacrymalis was $<6 \mathrm{~mm}$. The AHC result verified that CYN59 became monophiletic from clade 1, although this clade had an ancestor of CYN45. This result showed that morphometric characters could classify coral spesimens, although the clades were still unclear (Figure 3 and Figure 4). Because morphometric characters had a high plasticity and were influenced by environmental factors (Stefani et al., 2008; Huang et al., 2009; Schmidt-Roach et al., 2012). Paz-García et al. (2015) reported that Pocillopora damicornis change into $P$. inflata, coincided with a storm of high and low turbidity. Corals could modify their morphology to cope with environmental change with variation between habitats over time (Prada et al., 2008). Environmental changes in the sea (such as light, current patterns, sediment transport), force marine organisms to adapt with it (Hilbish, 1985; Doebeli and Dieckmann, 2003).

\section{Descriptive characters}

Descriptive character that differentiate between coral $C$. lacrymalis and $A$. deshayesiana were Septal Teeth (ST), Septa or Paliform Lobes (SPL), and Costae dentation (CD) (Table 3). Septal teeth (ST) on all of coral $A$. deshayesiana were big and point shaped, while C. lacrymalis finer and smaller (Figure 6). ACT21 had different shape, 
ILMU KELAUTAN September 2016 Vol 21(3):107-116

Table 3. Difference of descriptive characters between C. lacrymalis with A. deshayesiana

\begin{tabular}{lcc}
\hline \multicolumn{1}{c}{ Character } & C. lacrymalis & A. deshayesiana \\
\hline Corallite Shape & Solitary & Solitary \\
Septal Teeth & Large & Acute or small \\
Budding Type & None & None \\
Continuity of Costae & Continous & Continous \\
Septal and Paliform Lobes & Sometimes Paliform & Sometimes Septal \\
Columella Structure & Styliform & Styliform \\
Wall Structure & Synapticulothecal & Synapticulothecal \\
Costae Pattern & Equal & Equal \\
Costae Dentation & Short & Fine \\
Costae Alignment & Present & Present \\
Coenesteum & Smooth & Smooth \\
\hline
\end{tabular}
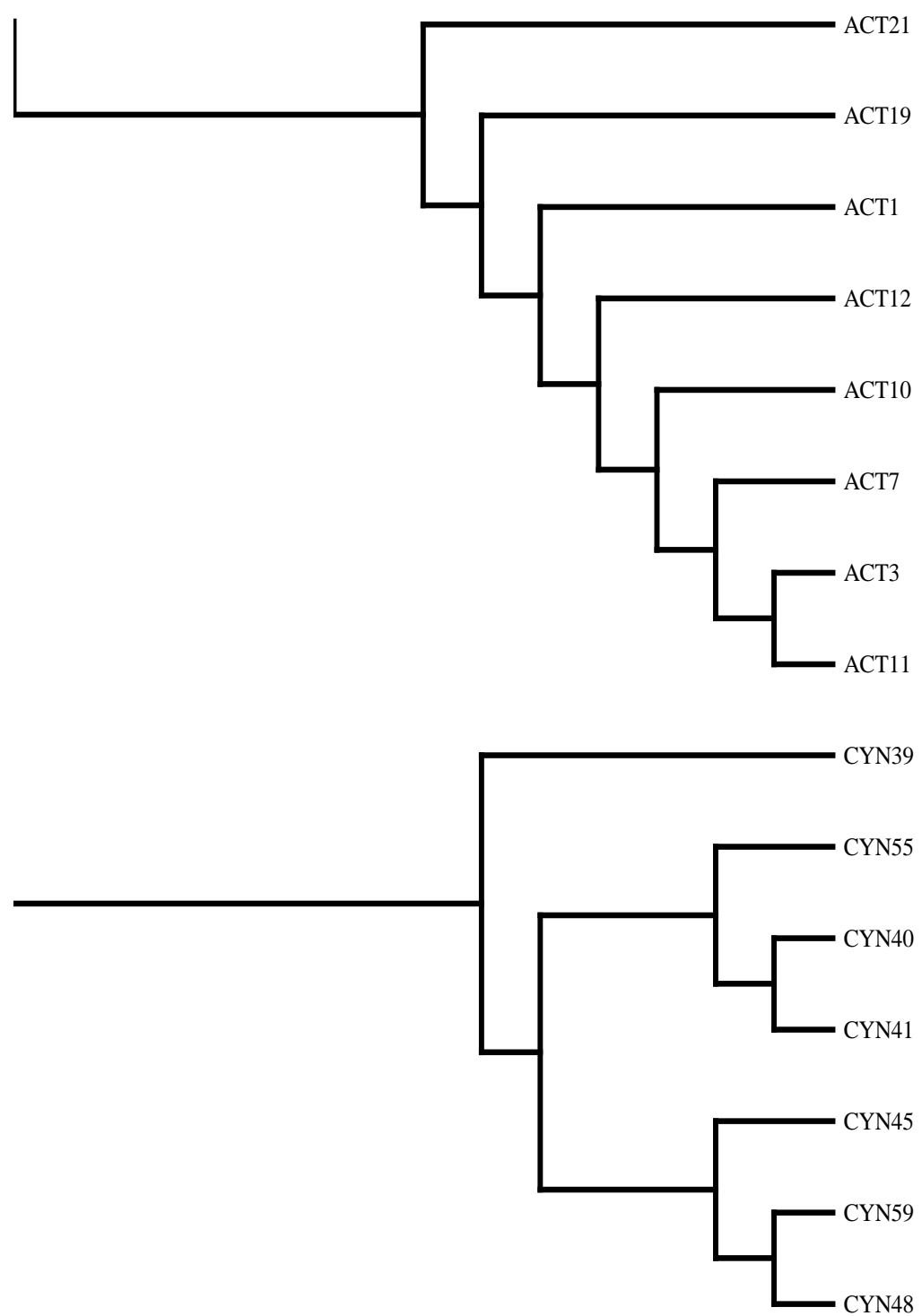

Figure 5. Cladogram based on descriptive characters with Unweighted Pair Group Method with Arithmetic Mean (UPGMA) method Note. Description: ACT (Acanthophyillia deshayesiana); CYN (Cynarina lacrymalis) 

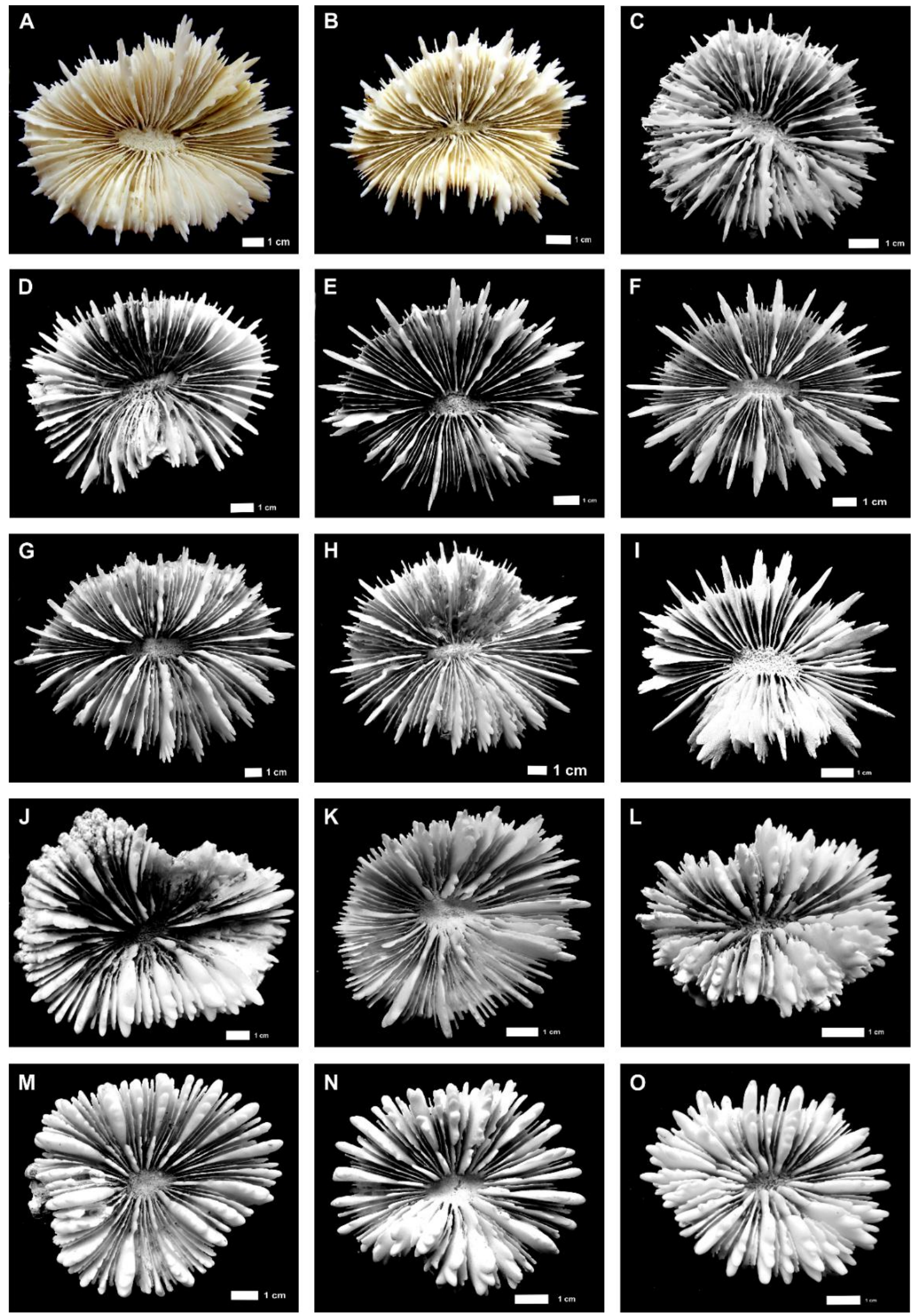

Figure 6. Comparison skeleton between C. lacrymalis with A. deshayesiana: A-H), A. deshayesiana; and I-0) C. lacrymalis 
namely the septal teeth of thick and spiky, whilst CYN39 was large and spiky, which opposite descriptive.

Septal teeth in each genus is different to distinguish morphometric characters of Family Faviidae (Budd and Stolarski, 2011). Septal teeth differences were also found in Family Faviidae between the Atlantic and Pacific (Budd and Stolarski, 2009; Budd and Stolarski, 2011), so it is possible a different location is able to give changes on coral morphology. Existence of SPL also differ between coral $C$. lacrymalis with $A$. deshayesiana. $A$. deshayesiana had pali which develops into septa, while C. lacrymalis has very clearly formed pali. Exceptions were found in CYN39 which the pali developed into septa. Budd and Stolarski (2009) showed that septa and pali on coral C. lacrymalis well developed.

Generally, there has no pali in Family Mussidae like species Scolymia cubensis, Scolymia vitiensi, Favia speciosa, and Favia cf.lizardensis, but there are exceptions to C. lacrymalis becausethis unique coral has septal and welldeveloped pali (Budd and Stolarski, 2009; Kongjandtre et al., 2012). Character to differenciate between $C$. lacrymalis with $A$. deshayesiana is Costae Dentation (CD). A. deshayesiana has fine of costae dentation, while C. lacrymalis has short of costae dentation.

The UPGMA results demonstrated a cladogram which forms the big and small groups. Phylogeny tree divides into 2 groups, namely group of C. lacrymalis and A. deshayesiana (Figure 5). Each coral had a different descriptive character, especially in C. lacrymalis which had a larger and blunt teeth shape, compared to $A$. deshayesiana with a thin and more pointed theeth shape (Figure 6). Acantophyllia deshayesiana with C. lacrymalis based on the descriptive character was able to distinguish clearly.

\section{Conclusion}

The study concludes that the groupings based on morphometric characters could not differentiate C. lacrymalis with $A$. deshayesiana, while the descriptive character grouping can already distinguish them separately.

\section{Acknowledgments}

The authors thank to Dirjen Pendidikan Tinggi (DIKTI) for providing the research grants through Beasiswa Pendidikan Pascasarjana Dalam Negeri (BPPDN) Year 2013. Dr. Agus Budianto from
Oceanographic Research Center Indonesian Institute of Sciences (P2O- LIPI) who has helped in collecting samples.

\section{References}

Arrigoni, R., Richards, Z.T., Chen, C.A., Baird, A.H. \& Benzoni, F., 2014a. Taxonomy and phylogenetic relationships of the coral genera Australomussa and Parascolymia (Scleractinia, Lobophylliidae). Contributions to Zoology., 83(3):195-215. doi: 10.1016/j.ympev.2014. 01.010.

Arrigoni, R., Stefani, F., Pichon, M., Galli, P. \& Benzoni, F. 2012. Molecular phylogeny of the robust clade (Faviidae, Mussidae, Merulinidae, and Pectiniidae): an Indian Ocean perspective. Molecular Phylogenetics and Evol., 65(1): 183193. doi: 10.1016/j.ympev.2012.0 6.001.

Arrigoni, R., Terraneo, T.I., Galli, P. \& F. Benzoni. 2014b. Lobophylliidae (Cnidaria, Scleractinia) reshuffled: pervasive non-monophyly at genus level. Molecular Phylogenetics and Evol. 73:6064. doi: 10.1016/j.ympev.2014.01.010.

Benzoni, F., Arrigoni, R., Stefani, F., \& Stolarski, J., 2012. Systematics of the coral genus Craterastrea (Cnidaria, Anthozoa, Scleractinia) and description of a new family through combined morphological and molecular analyses. Systematics and Biodiversity 10(4):417-433. doi: 10.1080/1472000.2012. 744369.

Best, M.B. \& Hoeksema, B.W. 1987. New Observations on scleractinian coral from Indonesia: 1. Free-living species belonging to the Faviina. Zoologische Mededelengin 61(27): 387-403.

Budd, A.F., Fukami, H.. Smith, N.D. \& Knowlton, N. 2012. Taxonomic classification of the reef coral family Mussidae (Cnidaria: Anthozoa: Scleractinia). Zoolog. J. Linnean Soc. London 166(3):465-529. doi:10.1111/j.1096-3642. 2012.00855.x.

Budd, A.F. \& Stolarski, J. 2009. Searching for new morphological characters in the systematics of scleractinian reef corals: comparison of septal teeth and granules between Atlantic and Pacific Mussidae. Acta Zoologica 90(2):142-165. doi: 10.1111/j.1463-6395.2008.00345.x.

Budd, A.F. \& Stolarski, J. 2011. Corallite Wall and Septal Microstructure in Scleractinian Reef 
Corals: Comparison of Molecular Clades Within the Family Faviidae. J. Morphology 272(1):6688. doi: 10.1002/jmor.10899

Casebolt, S.N. 2011. Phylogenetic analysis and quantitative assessment of micromorphology and microstructure in the coral family Mussidae (Scleractinia). [Desertation]. University of lowa.

Doebeli, M. \& U. Dieckmann. 2003. Speciation along environmental gradients. Nature 421(6920): 259-264. doi:10.1038/nature01274.

Filatov, M.V., Frade, P.R., Bak, R.P.M., Vermeij, M.J.A. \& Kaandorp, J.A. 2013. Comparison between colony morphology and molecular phylogeny in the Carribean Scleractinian Coral Genus Madracis. PLoS ONE 8(8):e71287. doi: 10.371/journal.pone.0071287.

Flot, J.F., Magalon, H., Cruaud, C., Couloux, A. \& Tiller, S. 2008. Patterns of genetic structure among Hawaiian corals of the genus Pocillopora yield clusters of individuals that are compatible with morphology. Comptes Rendus Biologies 331(3):239-247. doi:10.1016/j.crvi .2007.12.0 03 .

Hilbish, T.J. 1985. Demographic and temporal structure of an allele frequency cline in the mussel Mytilus edulis. Mar. Biol. 86(2):163171. doi: 10.1007/BF00399023.

Huang, D., Benzoni, F., Fukami, H., Knowlton, N., Smith, N.D. \& Budd, A.F. 2014. Taxonomic classification of the reef coral families Merulinidae, Montastraeidae, and Diploastraeidae (Cnidaria: Anthozoa: Scleractinia). Zoolog. J. Linnean Soc. 171(2): 277-355. doi: 10.1111/zoj.12 140.

Huang, D., Meier, R. Todd, P.A. \& Chou, L.M. 2009. More evidence for pervasive paraphyly in scleractinian corals: systematic study of Southeast Asian Faviidae (Cnidaria; Scleractinia) based on molecular and morphological data. Molecular Phylogenetics and Evol. 50(1):102-116. doi:10.1016/j. ympev.2008.10.012.

Kitano, Y.F., Benzoni, F., Arrigoni, R., Shirayama, Y., Wallace, C.C. \& Fukami, H. 2014. A phylogeny of the family Poritidae (Cnidaria, Scleractinia) based on molecular and morphological analyses. PLOS ONE 9(S):e98406. doi: 10.137 1/journal.pone.0098406.
Kongjandtre, N., Ridgway, T., Cook, L.G., Huelsken, T., Budd, A.F., \& Hoegh-Guldberg, O. 2012. Taxonomy and species boundaries in the coral genus Favia Milne Edwards and Haime, 1857 (Cnidaria: Scleractinia) from Thailand revealed by morphological and genetic data. Coral Reefs 31(2):581-601. doi: 10.1007/s00338-011-08 69-5.

Marti-Puig, P., Forsman, Z.H., Haverkort-Yeh, R.D., Knapp, I.S.S., Maragos, J.E. \& Toonen, R.J. 2014. Extreme phenotypic polymorphism in the coral genus Pocillopora; miro-morphology corresponds to mitochondrial groups, while colony morphology does not. Bull. Mar. Sci. 90(1). doi: 10.5343/bms.2012.1080.

Oppen, M.J.H.V., Willis, B.L., Vugt, H.W.J.A.V. \& Miller, D.J. 2000. Examination of species boundaries in the Acropora cervicornis group (Scleractinia, Cnidaria) using molecular DNA sequence analyses. Molecular Ecol. Resources 9(9):1363 -1373. doi:10.1046/j.1365-294x.2 000.0101 $0 . x$.

Paz-García, D.A., Hellberg, M.E., García-de-León, F.J. \& Balart, E.F. 2015. Switch between Morphospecies of Pocillopora Corals. The American Naturalist 186(3):434-440. doi: 10.1086/682363.

Prada, C., Schizas, N.V. \& Yoshioka, P.M. 2008. Phenotypic plasticity or speciation? A case from a clonal marine organism. BMC Evolutionary Biol. 8(47) doi: 10.1186/1471-2148-8-47.

Schmidt-Roach, S., Lundragen, P., Miller, K.J., Gerlach, G., Noreen, A.M.E. \& Andreakis, N. 2012. Assesing hidden species diversity in the coral Pocillopora damicornis from Eastern Australia. Coral Reefs. 32(1):161-172. doi: 10.1007/s00338-012-0959-z.

Stefani, F., Benzoni, F., Pichon, M., Mitta, G. \& Galli, P. 2008. Genetic and morphometric evidence for unresolved species boundaries in the coral genus Psammocora (Cnidaria; Scleractinia). Hydrobiologia 596(1):153-172. doi:10.1007/ s10750-007-9092-3.

Stobart, B. 2000. A taxonomic reappraisal of Montipora digitata based on genetic and morphometric evidence. Zoological Stud. 39(3):179-190.

Swofford, D.L. 2002. PAUP*. Phylogenetic Analysis Using Parsimony (*and Other Methods). Version 4. Sunderland, Massachusetts: Sinauer Associates. 
Wolstenholme, J.K., Wallace, C.C., \& Chen, C.A. 2003. Species boundaries within the Acropora humilis species group (Cnidaria; Scleractinia): a morphological and molecular interpretation of evolution. Coral Reefs 22(2):155-166. doi: 10.1007/s00338-003-0299-0. 